\title{
PENGARUH METODE PERMAINAN BOARDGAME EDUCATION "PHARMAPOLEIN" TERHADAP PEMAHAMAN MATERI KEFARMASIAN MAHASISWA
}

\author{
Ilham Alifiar, Vidya Febrasca Tenderly, Annisa Nurhayati \\ STIKes Bakti Tunas Husada Tasikmalaya \\ e-mail : ilhamalifiar@stikes-bth.ac.id ; vfebrasca@gmail.com; \\ annisanurhaaayati@gmail.com
}

\begin{abstract}
Mission of pharmacy education is to develop and nurture skills in lifelong learning. Broad insight, skills in communication, and teamwork is a must for the pharmaceutical profession. The learning method greatly affects the results of understanding each individual, especially in understanding pharmaceutical material which is considered difficult. Educational games are used as a teaching method because they help complement and strengthen the material being taught. Board games have continued to grow in popularity and the pedagogical value of the games has been supported many times. So, this board game is designed to have enough challenging elements to nurture student interest. The game tactic used collaboration and competition in the classroom. Competition has been found to increase motivation. Thus, that motivation can be used to understand the pharmaceutical material contained in the game. Aim this study is to determine the potential modification of the monopoly board game in increasing student comprehension of pharmaceutical material. The pharmapolein game was examined on both pharmacy and non-pharmacy student respondents $(n=12)$. From the test, it was obtained a correlation value of and 0.885 and a significance value of 0.000 , so the conclusion was that the board game game could increase student knowedge in mastery of pharmaceutical science.
\end{abstract}

Keywords: Board Games, Pharmapolein, Pharmacy

\begin{abstract}
ABSTRAK
Misi pendidikan farmasi adalah untuk mengembangkan dan membina keterampilan dalam belajar seumur hidup. Wawasan luas, keterampilan dalam komunikasi serta kerjasama tim menjadi suatu keharusan yang dimiliki oleh profesi farmasi. Metode pembelajaran sangat mempengaruhi hasil pemahaman setiap individu terutama dalam memahami materi farmasi yang dirasa sulit. Permainan edukasi digunakan sebagai strategi pengajaran dikarenakan membantu melengkapi dan memperkuat materi yang diajarkan. Permainan papan terus meningkat popularitasnya dan nilai pedagogis dari permainan tersebut telah didukung berulang kali. Jadi, permainan papan ini dirancang untuk memiliki elemen yang cukup menantang untuk memelihara minat siswa. Taktik permainan
\end{abstract}


menggunakan kolaborasi dan kompetisi dalam kelas. Kompetisi telah ditemukan dapat meningkatkan motivasi seseorang. Sehingga motivasi tersebut dapat dimanfaatkan untuk memahami materi farmasi yang dimuat dalam permainan. Untuk mengetahui potensi modifikasi permainan papan monopoli dalam meningkatkan pemahaman mahasiswa dalam materi farmasi. Permainan pharmapolein diuji kepada responden mahasiswa farmasi dan non - farmasi $(n=12)$. Dari pengujian didapatkan nilai korelasi sebesar dan 0,885 dan nilai signifikansi sebesar 0,000 sehingga didapatkan kesimpulan bahwa adanya permainan board game ini dapat meningkatkan pengetahuan mahasiswa dalam penguasaan ilmu kefarmasian.

Keywords : Permainan Papan, Pharmapolein, Farmasi

\section{PENDAHULUAN}

Salah satu misi pendidikan farmasi adalah untuk mengembangkan dan membina keterampilan dalam belajar seumur hidup, karena pendidikan profesional tidak semata berakhir dengan kelulusan. Wawasan luas, keterampilan dalam komunikasi serta kerjasama tim menjadi suatu keharusan yang dimiliki oleh profesi farmasi. Metode pembelajaran sangat mempengaruhi hasil pemahaman setiap individu terutama dalam kefarmasian. Setiap individu sering kali mengalami suatu keadaan yang menyebabkan timbulnya rasa jenuh dan bosan dalam belajar. Menurut data United Nation Educational Scientific and Cultural, minat baca masyarakat Indonesia sangat rendah, hanya $0,001 \%$ artinya hanya 1 dari 1000 orang yang memiliki minat membaca. Hal tersebut menjadi acuan dalam pengembangan yang memiliki korelasi dalam minat belajar, terutama dalam kefarmasian itu sendiri.

Permainan edukasi sebagai strategi pengajaran dapat diartikan sebagai pendekatan pengajaran yang memungkinkan siswa untuk meneliti berbagai bagian permainan dalam proses pembelajaran (Strode, 2019). Permainan edukasi bisa membantu melengkapi dan memperkuat materi yang diajarkan dengan mempromosikan partisipasi dan keterlibatan siswa dalam lingkungan belajar yang interaktif, menyenangkan, dan memotivasi. Hambatan utama penyebaran luas penggunaan pendidikan permainan terutama memakan waktu, biaya, dan ketidakhadiran dari game tervalidasi dan rancangan yang baik (Aburahma \& Mohamed, 2015). Permainan edukasi juga bermanfaat dalam meningkatkan fungsi kognitif sehingga membuat seseorang mampu berfikir cepat pada saat bermain, merupakan keterampilan yang dapat membantu dalam kehidupan (Alshammari, 2013).

Permainan papan terus meningkat popularitasnya dan nilai pedagogis dari permainan tersebut telah didukung berulang kali. Permainan menjaga seseorang tetap terlibat dan tingkat keterlibatan diterjemahkan langsung ke dalam waktu yang dihabiskan untuk bermain, dan dengan demikian, waktu yang dihabiskan digunakan untuk memahami materi yang tersedia dalam permainan. Siswa sarjana di kelas tingkat atas lebih mungkin untuk terlibat dalam studi kolaboratif produktif daripada yang di kelas tingkat bawah. Jadi, permainan papan ini dirancang untuk memiliki elemen yang cukup menantang untuk memelihara minat siswa. Taktik permainan menggunakan kolaborasi dan kompetisi dalam kelas. Kompetisi telah ditemukan dapat meningkatkan motivasi seseorang. Sehingga motivasi tersebut dapat dimanfaatkan untuk memahami materi yang dimuat dalam permainan papan (Motz et al., 2019). Pembelajaran menggunakan permainan papan telah digunakan di beberapa bidang pelatihan medis dan profesional kesehatan terkait 
dan telah terbukti meningkatkan pengetahuan, kesenangan dan minat pada subjek (Whittam \& Chow, 2017).

Menurut penelitian Strode (2019), permainan papan umumnya mengembangkan pemikiran logis sebesar $27 \%$, termasuk keterampilan matematika, keterampilan komunikasi, keterampilan bahasa, keterampilan membaca dan berbicara sebesar $23 \%$, berpikir kreatif, keterampilan menghasilkan ide, fantasi dan imajinasi sebesar $14 \%$; serta kerja sama sebesar $10 \%$. Banyak responden yang berpendapat bahwa permainan melatih perhatian dan kesabaran sebesar $7 \%$ serta, dan ini penting, kemampuan tidak hanya untuk menerima kekalahan sendiri dan kemenangan orang lain sebesar $4 \%$, tetapi juga untuk belajar dan menarik kesimpulan dari kekalahan. Permainan papan monopoli merupakan salah satu permainan papan populer yang paling banyak disebutkan oleh responden (Strode, 2019).

Maka dari itu, modifikasi permainan monopoli sebagai metode pembelajaran dilakukan untuk membantu memahami materi kefarmasian. Monopoli sebagai permainan yang sudah dikenal luas dan disukai banyak orang diharapkan mampu meningkatkan motivasi dan minat seseorang untuk memahami, menyelesaikan dan memenangkan permainan tersebut sehingga tanpa disadari seseorang tersebut telah belajar materi kefarmasian.Tujuan dari penelitian ini adalah untuk membuat suatu metode pembelajaran yang dapat mempermudah pemahaman materi kefarmasian. Permasalahan dalam penelitian ini adalah apakah metode pembelajaran modifikasi permainan monopoli (Pharmapolein) dapat meningkatkan pemahaman kefarmasian siswa?

\section{Pembelajaran Farmasi}

Bagaimana mahasiswa farmasi memahami, memproses, dan mengembangkan kemampuannya dalam pembelajaran merupakan masalah penting bagi dosen untuk dipertimbangkan, khususnya saat proses pembelajaran pada tingkat professional. Maka, dibutuhkan pengembangan metode baru untuk proses pembelajaran yang digunakan untuk mempermudah dalam kompleksitas dari praktik klinis. Gaya belajar yang cocok dapat bermanfaat sebagai jalur alternatif dalam menerima dan memahami informasi. Oleh karena itu, dapat dikatakan bahwa pilihan gaya belajar yang cocok dapat berpengaruh dalam pencapaian akademik (Tsingos et al., 2015). Pembelajaran tradisional mungkin tidak optimal digunakan untuk membantu belajar mahasiswa dan menerapkannya dalam teori ke praktik sehari - hari. Penelitian terbaru pada bidang non farmasi menyarankan bahwa strategi pembelajaran aktif dapat menarik perhatian mahasiswa secara signifikan, bahkan dalam perkuliahan luas. Saat ini, kurikulum farmasi menggabungkan pembelajaran aktif pedagogies untuk mempromosikan pembelajaran tingkat tinggi. (Bleske et al., 2016).

\section{Pembelajaran Farmasi di Amerika Serikat}

Permainan edukasi dapat dipertimbangkan sebagai metode pembelajaran eksperimen yang memiliki kontribusi positif bagi mahasiswa. Peneliti mengeksplorasi pengaruh dari beberapa permainan edukasi terhadap kepuasan mahasiswa, pengetahuan, perubahan sikap, dan partisipasi. Dari 13 studi ditemukan beberapa kriteria yang dipublikasikan diantara tahun 1995 dan 2013 dari sekolah farmasi di Amerika Serikat. Studi mengenai permainan dalam pembelajaran farmasi lebih sedikit dibandingkan bidang ilmu kesehatan lainnya, seperti kedokteran dan keperawatan. Berdasarkan jumlah murid dan mata kuliah, beberapa permainan berbeda telah dilaporkan. Patel dan Barclay et al mengimplementasikan beberapa permainan edukasi untuk menambah pengetahuan mahasiswa dalam mata kuliah farmakoterapi dan 


\section{kebanyakan mahasiswa yang berpartisipasi merasakan bahwa permainan tersebut membantu \\ Permainan Papan Sebagai Pembelajaran Farmasi} memahami pembelajaran. Selain bermain, mereka juga mengembangkan kemampuan berkompetisi dengan adanya hadiah bagi pemenang. Keuntungan utama dari permainan tersebut diantaranya partisipasi aktif dari mahasiswa dan kegembiraan mereka saat bermain. Permainan edukasi membantu meyampaikan pembelajaran dengan lebih nyaman tanpa adanya tekanan (Aburahma \& Mohamed, 2015).

\section{Pembelajaran Farmasi di Indonesia}

Kurikulum pendidikan kefarmasian mulai mengembangkan mata kuliah yang berfokus pada pengembangan soft skill mahasiswa yang dapat meningkatkan kemampuannya dalam menyediakan informasi obat yang valid dan terpercaya. Mata kuliah sistem informasi obat merupakan mata kuliah yang ditujukan untuk mengembangkan pengetahuan dan kemampuan mahasiswa Farmasi Jurusan Farmasi FMIPA UNUD sebagai kajian dan penggunaan informasi obat yang valid dan terpercaya dalam pemberian pelayanan informasi obat. Permasalahan dalam sistem pendidikan kefarmasian adalah adanya kesenjangan antara teori dan penerapan praktek klinisnya. Sebagian besar mahasiswa Farmasi kesulitan dalam mengimplementasikan pengetahuan teoritis ke dalam praktek pelayanan kefarmasian. Penggunaan metode pembelajaran problem based learning ( $\mathrm{PBL})$ merupakan salah satu cara untuk mengembangkan kemampuan implementasi pengetahuan teoritis mahasiswa ke dalam kondisi nyata dalam praktek klinis (Larasanty et al., 2016).

Permainan papan, Race to Glucose, telah diciptakan dan diimplementasikan untuk meningkatkan kenyamanan mahasiswa farmasi dalam mempelajari jalur metabolisme. Kebanyakan mahasiswa dalam survey setuju bahwa permainan papan dapat membantu mereka belajar beberapa aspek mengenai jalur metabolisme yang tersedia dalam permainan (regulasi, intermediet, dan hubungan intrajalur) tapi tidak dengan yang lainnya (reaksi, formasi energi molekul, dan hubungan kondisi biologis). Secara keseluruhan hasil yang didapatkan meningkatkan pengetahuan mahasiswa pada materi yang tersedia dalam permainan, setelah dilakukan analisis pertanyaan sebelum dan setelah permainan dilakukan. Secara umum, mahasiswa menikmati permainan tersebut dan menganggap bahwa permainan tersebut bermanfaat untuk aktifitas tim (Rose, 2011). Pembelajaran menggunakan permainan papan membangun gagasan sebagai lingkungan belajar alternatif. Permainan papan adalah ruang untuk pembelajaran matematika, interaksi sosial, pemikiran komputasi, dan untuk terlibat dalam berbagai praktik. Permainan papan juga memungkinkan pembelajaran berbagai konten, dan memotivasi pemain untuk mempelajari lebih lanjut tentang suatu topik. Dari data tersebut terbukti bahwa permainan papan adalah ruang yang memungkinkan pemain untuk terlibat dalam pembelajaran dan mendemonstrasikan pemahaman tentang konsep yang kompleks. Memang, permainan papan memfasilitasi pemahaman tentang konsep yang kompleks (misalnya, teknik, keuangan, dan sains) (Bayeck, 2020).

Tabel 1. Keterampilan yang dikembangkan dengan permainan papan (Strode, 2019) 


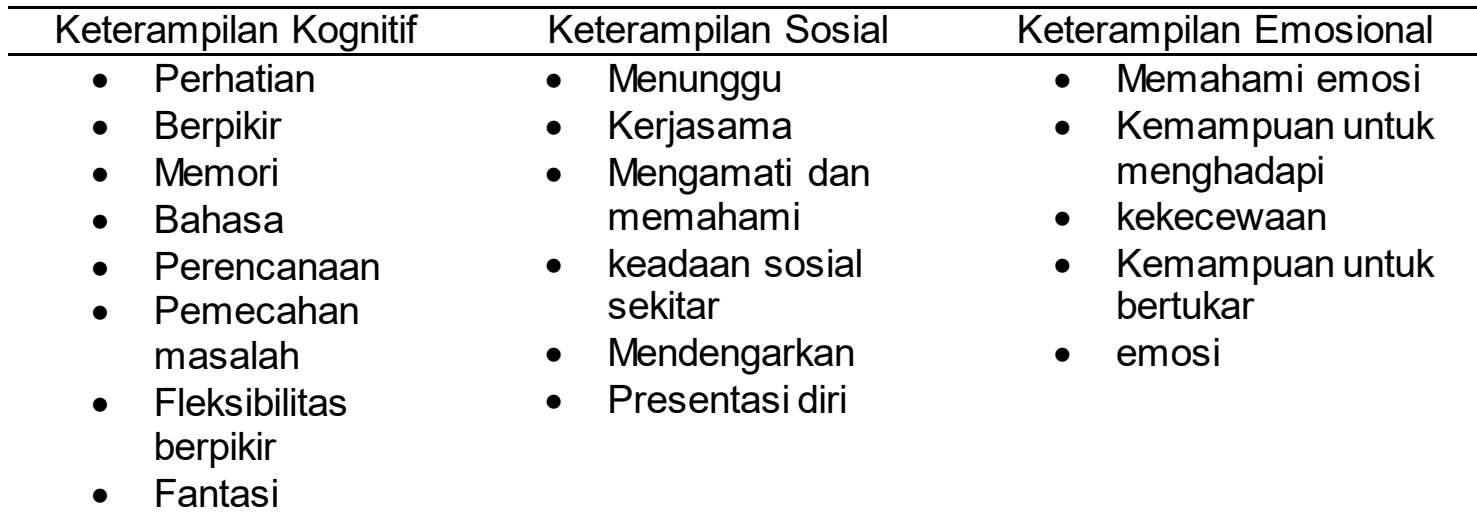

\section{METODE}

\section{Alat dan bahan}

Papan permainan pharmapolein, dua buah dadu, empat buah perwakilan pemain, beberapa buah gedung, kartu scienza (informasi), kartu nito (pertanyaan), kartu kepemilikan, uang pharmapolein, peraturan permainan.

\section{Premis Permainan}

Petak permainan diibaratkan sebagai pabrik sediaan farmasi, pemain harus berusaha untuk menguasai semua pabrik. Pemain akan menjawab setiap pertanyaan dari kartu nito dan mendapatkan jawaban pertanyaan yang termuat di kartu scienza.

\section{Peraturan Permainan}

Pada permulaan permainan, setiap pemain berada di petak start dan melempar dadu pertama. Selanjutnya, pemain dapat membeli petak - petak pabrk sediaan farmasi sehingga menjadi milik pemain tersebut. Jika ada pemain lain yang menempati petak tersebut maka pemain tersebut harus membayar pajak kepada pemilik petak. Jika pemain menempati petak Scienza maka akan mendapatkan kartu informasi pegetahuan kefarmasian. Jika pemain menempati petak nito maka akan mendapatkan kartu pertanyaan yang harus dijawab dengan waktu 30 detik, jika pemain tidak dapat menjawab dengan benar maka diharuskan masuk penjara. Pemenang dalam permainan adalah pemain yang dapat menguasai semua petak pabrik sediaan farmasi dan membuat pailit pemain lainnya.

\section{Responden Penelitian}

Responden penelitian terdiri dari mahasiswa jurusan farmasi dan nonfarmasi $(n=12)$, mahasiswa farmasi $(n=6)$, dan mahasiswa non - farmasi $(n=6)$.

\section{Pengujian Pretest}

Pengujian dilakukan sebelum bermain permainan pharmapolein dengan mengerjakan soal yang terdiri dari 50 soal.

\section{Pengujian Posttest}

Pengujian dilakukan setelah bermain permainan pharmapolein dengan mengerjakan soal yang terdiri dari 50 soal.

\section{Analisis Data}

Analisis data dilakukan menggunakan software IBM SPSS Statistics 25, dengan menggunakan uji $t$ independen untuk melihat perubahan dan signifikansi pre dan pos test. Selanjutnya dilakukan uji korelasi spearman untuk mengetahui hubungan permainan pharmapolein dengan pengetahuan responden. Nilai signifikansi digunakan untuk mengetahui ada atau tidaknya pengaruh dengan nilai probabilitas 0,05 . 
HASIL

Penelitian ini bertujuan untuk mengetahui tingkat pengetahun sampe uji setelah mengikuti permaninan board game yang sudah dimodifkasi oleh peneliti.

Penelitian ini dilakukan dengan melakukan uji pre rest dan post test pada sampel uji yang mengikuti permainan board game yang sudah dimofidikasi oleh peneliti. Pretest dan postest berjumlah 50 pertanyaan yang terkait dengan isi permainan.

Pada penelitian ini didapatkan 6 orang control positif yang merupakan mahasiswa farmasi serta 6 orang control negative yang bukan merupakan mahasiswa farmasi.

\section{PEMBAHASAN}

Pada penelitian ini, didapatkan sebanyak 12 orang sampel uji yang terbagi menjadi control positif dan 6 orang control positif. Baik control positif maupun control negative diperlakukan sama. Kedua kelompok sampel terlebih dahulu mengisi pretest yabg disediakan oleh peneliti, kemudian kedua kelompok sampel mengikuti permainan boarad game yang sudah dimodifikasi oleh peneliti, dan sesudah permainan berakhir, kedua kelompok uji dilakukan post test untuk meneliti sejauh mana peningkatan pengetahun setelah mengikuti permanainan.

Dari penelitian didapatkan rata-rata skor pre test pada kelompok uji positif sebesar 92,83. Sedangkan pada kelompok uji negative didapatkan ratarata skor pre test sebesar 77 . Hal ini wajar karena kelompok uji positif merupakan mahasiswa farmasi, dan mayoritas pertanyaan pada uji pengetahuan merupakan pertanyaan yang terkait degan ilmu kefarmasian.sedangkan kelompok uji negative merupakan mahasiswa non farmasi.

Pada uji post test yang dilakukan setelah permainan berakhir, hasil skor rata-rata kelompok uji positif naik menjadi 97,33 dan skor rata-rata kelompok uji negative naik menjadi 82. Table data hasil skor rata-rata ledua kelompok disajikan sebagai berikut :

Tabel 2 . Hasil Uji

\begin{tabular}{lccc}
\hline Kelompok & $\begin{array}{c}\text { Skor rata-rata Pre } \\
\text { test }\end{array}$ & $\begin{array}{c}\text { Skor rata-rata Post } \\
\text { test }\end{array}$ & Uji korelasi \\
\hline Uji positif & 92,83 & 97,33 & \multirow{2}{*}{$\begin{array}{c}\text { Pearson }=0,885^{\star *} \\
\mathrm{P}=0,000\end{array}$} \\
\hline Uji negatif & 77,00 & 82,00 & \\
\hline
\end{tabular}

Dari data table diatas terlihat secara umum bahwa permainan yang dilakukan dapat meningkatkan tingkat pengetahuan sampel uji. Namun belum dapat dikatan signifikan secara statistic apakah bermakna atau tidak, dan belum dapat dikatakan bahwa adanya permainan tersebut berkorelasi secara baik terhadap peningkatan pengetahuan sampel. Untuk itu dilakukan uji T dan uji korelasi spearman. Hasil uji $T$ terhadap sampel uji didapatkan sebesar 0,000. Artinya terdapat hubungan yang signifikan antara pengetahuan sampel uji sebelum mengikuti permainan dan pengetahuan sampe; uji setelah mengikuti permainan.

Hasil uji korelasi spearman didapatkan nilai koefisian korelasi sebesar 0,885 , kemudian didpatkan pula nilai signifikansi 0,000 , serta terdapat bintang $\left({ }^{* *}\right)$ pada hasil yang keluar.

Nilai korelasi dengan nilai 0.885 menunjukan bahwa hubungan 2 variabel sangat kuat, dalam hal ini membuktikan bahwa adanya permainan board game ini terbukti dapat meningkatkan pengetahuan dari sampel uji. Hal ini semakin diperkuat dengan nilai 
signifikansi 0,000 yang bermakna adanya korelasi yang signifikan.

\section{DAFTAR PUSTAKA}

Aburahma, M. H., \& Mohamed, H. M. (2015). Educational games as a teaching tool in pharmacy curriculum. American Journal of Pharmaceutical Education, 79(4). https://doi.org/10.5688/ajpe79459

Alshammari, E. (2013). Implementing Educational Game in Pharmacy. International Journal Of Pharmaceutical Quality Assurance, 11(01), 74-82. doi: 10.25258/ijpqa.11.1.23

Bayeck, R. Y. (2020). Examining Board Gameplay and Learning: A Multidisciplinary Review of Recent Research. Simulation and Gaming, 51(4), 411-431. https://doi.org/10.1177/1046878119 901286

Bleske, B. E., Remington, T. L., Wells, T. D., Klein, K. C., Guthrie, S. K., Tingen, J. M., Marshall, V. D., \& Dorsch, M. P. (2016). A randomized crossover comparison of teambased learning and lecture format on learning outcomes. American Journal of Pharmaceutical Education, $\quad 80(7)$, 1-5. https://doi.org/10.5688/ajpe807120

Indonesia | UNESCO UIS. (2020). Retrieved 17 October 2020, from http://uis.unesco.org/en/country/id

Larasanty, L. P. F., Wulandasari, N. L. P. D., \& Sari, R. A. D. P. (2016).

PENGARUH

PEMBELAJARAN

MASALAH

KEMAMPUAN

FARMASI

DALAM

MAHASISWA

Problem Based Learning Method

Among Pharmacy Student

Capability on Drug Information
Aspect. Buletin Penelitian Sistem Kesehatan, 19(3), 211-217.

Motz, V., Koneval, T., Bennett-Toomey, J., Suniga, R., \& Runestad Connour, J. (2019). The Survival of the Physiologist: A Human Anatomy and Physiology Game. HAPS Educator, 23(1), 37-44. https://doi.org/10.21692/haps.2019. 006

Rose, T. M. (2011). A board game to assist pharmacy students in learning metabolic pathways. American Journal of Pharmaceutical Education, 183. https://doi.org/10.5688/ajpe759183

Strode, A. (2019). a Board Game As a Teaching Tool in a Pedagogically Psychological Perspective. EDULEARN19 Proceedings, 1(July), 5437-5444. https://doi.org/10.21125/edulearn.20 19.1333

Tsingos, C., Bosnic-Anticevich, S., \& Smith, L. (2015). Learning styles and approaches: Can reflective strategies encourage deep learning? Currents in Pharmacy Teaching and Learning, 7(4), 492504.

https://doi.org/10.1016/j.cptl.2015.0 4.006

Whittam, A. M., \& Chow, W. (2017). An educational board game for learning and teaching burn care: A preliminary evaluation. Scars, Burns \& Healing, 3, 205951311769001. https://doi.org/10.1177/2059513117 690012 